\title{
DEVELOPING COUNTRIES \\ IN BRITISH FICTION
}




\title{
DEVELOPING COUNTRIES \\ IN BRITISH FICTION
}

\author{
D. C. R. A. Goonetilleke
}

Senior Lecturer in English

University of Sri Lanka (Ceylon)

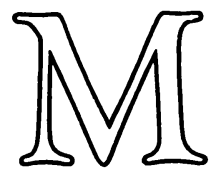


C D. C. R. A. Goonetilleke 1977

Softcover reprint of the hardcover 1st edition 1977 All rights reserved. No part of this publication may be reproduced or transmitted, in any form or by any means, without permission

First published 1977 by THE MACMILLAN PRESS LTD London and Basingstoke Associated companies in New York Dublin Melbourne Johannesburg and Madras

ISBN 978-1-349-03012-5

ISBN 978-1-349-03010-1 (eBook) DOI 10.1007/978-1-349-03010-1

This book is sold subject to the standard conditions of the Net Book Agreement 


\section{To CHINCHI, SURENDRA and DILHAN}




\section{Contents}

Page

Foreword

ix

Introduction 1

1 Antecedents 13

2 Challenges and problems of the Far East

(i): Conrad's Tales 33

3 Challenges and problems of the Far East

(ii): Conrad's Malayan novels 52

4 Conrad's Malayan novels: problems of authenticity 77

5 Conrad's African tales: ironies of progress 99

6 Conrad's Nostromo: the morality of 'material interests' 119

7 Difficulties of connection in India: Kipling and Forster 134

8 D. H. Lawrence: primitivism? 170

9 Joyce Cary: the clash of cultures in Nigeria 199

10 Between cultures 245

Notes and references 253

$\begin{array}{ll}\text { Select bibliography } & 271\end{array}$

$\begin{array}{ll}\text { Index } & 277\end{array}$ 


\section{Foreword}

I explored the subject of this book because it was alive with significance for people in both developed and developing countries and because it was concerned with a central evolving tradition of English literature. My inquiry benefited from the suggestions and criticism of Dr David Craig, who was not merely the supervisor of my research but a fine friend. I was encouraged by the interest of Professor E. F. C. Ludowyk at every stage in my work, and I received useful advice from Mr M. I. Kuruvilla when I was preparing the book.

My work on this subject was originally done for a thesis accepted for the degree of Ph.D. of the University of Lancaster. My research in Britain was made possible when I was awarded a scholarship by the Commonwealth Scholarship Commission in the U.K. I must thank the Commission and the British Council for helping to make my stay in Britain both very enjoyable and most instructive. I must also thank the staffs of several libraries, notably those of the University of Lancaster and the British Museum.

Parts of this book originally appeared in A Review of International English Literature (ARIEL), The Journal of Commonwealth Literature, The Kipling Journal, The Bulletin of the Association for Commonwealth Literature and Language Studies and The Ceylon Journal of the Humanities. Joseph Conrad's unpublished letter to T. Fisher Unwin, dated 14 April 1897, is quoted with the permission of the Brotherton Collection, University of Leeds.

I would like to thank the following who have kindly given permission for the use of copyright material: Edward Arnold (Publishers) Ltd for the extracts from $A$ Passage to India by E. M. Forster; Curtis Brown Ltd and Harper \& Row Publishers Inc., on behalf of the Estate of Joyce Cary, for the extracts from Aissa Saved, The African Witch and Mister Johnson; Laurence Pollinger Ltd and the Estate of the late Mrs Frieda Lawrence and Alfred A. Knopf Ltd, for the extract from The Plumed Serpent by D. H. Lawrence, published by William Heinemann Ltd; and A. P. Watt \& Son, on behalf of the late Mrs Elsie Bambridge and Eyre Methuen \& Co. Ltd, for the poem 'Recessional' from The Five Nations by Rudyard Kipling.

D. C. R. A. G. 